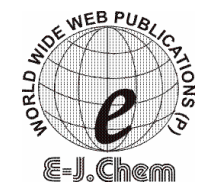

http://www.e-journals.net
ISSN: 0973-4945; CODEN ECJHAO

E-Journal of Chemistry

Vol. 5, No .1, pp. 177-184, January 2008

\title{
Mechanical Properties of Phenolic Composites Reinforced with Flax-g-copolymers Prepared under Different Reaction Conditions - A Comparative Study
}

\author{
SUSHEEL KALIA ${ }^{*}$ and B. S. KAITH \\ *Department of Chemistry, Singhania University, Pacheri Badi, Jhunjhunu - 333515 India \\ Department of Chemistry, NIT (Deemed University), Jalandhar - 144011 India \\ susheel_kalia@yahoo.com
}

Received 26 September 2007; Accepted 10 November 2007

\begin{abstract}
Graft copolymers of methyl methacrylate (MMA) and its binary mixtures such as MMA + ethyl acrylate (EA), MMA + acrylonitrile (AN), MMA + acrylic acid (AA), MMA + vinyl acetate (VA), MMA + acrylamide (AAm) and MMA + styrene (Sty) with flax fiber have been prepared in air (IA) and under the influence of microwave radiations (MWR). Synthesized flax-g-copolymers under two different reaction conditions were used as reinforcing material in the preparation of phenol-formaldehyde composites. Mechanical properties such as wear resistance, modulus of rupture (MOR), modulus of elasticity (MOE) and stress at the limit of proportionality (SP) were measured and a comparative studied has been made. It has been found that composites reinforced with flax-g-copolymers-MWR showed better mechanical properties in comparison to composites reinforced with flax-gcopolymers-IA
\end{abstract}

Keywords: Flax fiber, MMA, Grafts co-polymers, Mechanical properties.

\section{Introduction}

Natural fibers reinforced composites have received much attention due to their distinct advantages such as renewable source, biodegradability, high filling effect and nonabrasiveness. Because of tremendous changes in the quality of natural fibers, they are fast emerging as a reinforcing material in composites. Phenolic resin bonded Flax-particle boards were manufactured for construction industry and structure, chemical composition and mechanical resistance of Flax shives and Flax boards were compared with corresponding properties of wood particleboards ${ }^{1}$. Bentsianova et $a l^{2}$ have described the manufacturing process for wood particle board from wood alone, wood and hemp scotch or scotch alone. Kolosvary ${ }^{3}$ increased the water resistance of wood particle and hemp waste boards by preliminary thermal treatment of the particles. Particle boards made from pretreated 
materials showed lower water absorption and lower thickness swelling after soaking in water or after exposure to super-saturated water vapour for ten days than particle boards made from untreated materials. Water-proof building materials of increased strength and rigidity were manufactured at low costs from vermiculite, polyester resin binders, natural fiber waste, synthetic fibers, acrylic resins, paper, paperboard and wood fibers ${ }^{4}$. Work on reinforcement of composite soil with barley straw has been reported by Bouhicha et $a l^{5}$. Importance of Indigenous natural fiber in their applications in the preparation of composites over synthetic fibers has been reported by Paramasivam and Kalam ${ }^{6}$. Le et al. ${ }^{7}$ developed the novel short silk reinforced polybutylene succinate bio-composites by compression molding method and observed that there was enhanced improvement in tensile and flexural properties. Joseph et al. ${ }^{8}$ fabricated composites reinforced with banana fibers and glass fibers with varying fiber length and fiber loading. The analysis of tensile, flexural and impact properties of these composites revealed that the optimum length of the type required for banana fiber and glass fiber is different in phenol-formaldehyde resole material. Interlocking between the banana fiber and phenol formaldehyde resins was much higher than that between glass and phenol formaldehyde resin.

Wetting behaviour of Flax fiber and possible replacement of polypropylene fiber with Flax for the preparation of composites as reinforcement was studied by Askargorta et al. ${ }^{9}$. Escamilla et al. ${ }^{10}$ observed that grafting of polymethyl methacrylate or polybutylacrylate on the cellulosic fiber results in lower mechanical properties than those of the ungrafted cellulosic fibers for their applications in composites as reinforcing agent. Kaith et al. ${ }^{11-13}$ and Kalia et al. ${ }^{14-15}$ reported the mechanical studies of polymer composites reinforced with flax-g-copolymers.

Since the use of flax-g-copolymers as reinforcement for polymers is meagerly reported, therefore, in this paper reinforcement of phenol-formaldehyde matrix with flax-gcopolymers prepared under different reaction conditions have been reported and a comparative study has been made.

\section{Experimental}

Flax fiber (Linum usitatissimum) was obtained from the Department of Agronomy, CSK HP Agriculture University, Palampur (India). Phenol (Sd fine-chem ltd., India) and formaldehyde ( $\mathrm{CDH}$, India) were used as received. Monomers were washed with 5\% sodium hydroxide followed by water and were dried over anhydrous sodium sulphate. The dried monomers were distilled and the middle fraction was used. Composites were prepared in Compression Molding Machine (SANTEC India Ltd.). Libror AEG-220 (Shimadzu make) electronic balance was used for weighing purpose.

Wear-resistance testing of the composites was carried-out on Wear \& Friction Monitor (DUCOM, 20LE). MOR, MOE and SP of samples were tested on Universal Testing Machine (HOUNSFIELD, H25KS).

\section{Graft co-polymerization of MMA and its binary monomer mixtures onto flax}

Grafting of MMA and its binary monomer mixtures were carried out as per the methods reported earlier ${ }^{11-12,14}$.

The percentage grafting $\left(\mathrm{P}_{\mathrm{g}}\right)$ was calculated as follows:

$$
\mathrm{P}_{\mathrm{g}}=\frac{\mathrm{W}_{2}-\mathrm{W}_{1}}{\mathrm{~W}_{1}} \times 100
$$

Where $\mathrm{W}_{1}$ and $\mathrm{W}_{2}$ are the weights of original flax fibers and grafted flax fibers, respectively. 


\section{Preparation of resin}

Phenol-formaldehyde resin was prepared as per the method reported earlier ${ }^{11}$.

\section{Preparation of composites}

Phenol-formaldehyde resin was thoroughly mixed with fibers (10:0.5 w/w). After thorough mixing of the resin and fibers, the mixture was poured in molds. The surfaces of molds were coated on the inside with oleic acid to avoid adhesion of the mixture and to allow easy removal of the composites. The whole assembly was then placed inside the hot press and cured at $90{ }^{\circ} \mathrm{C}$ and a pressure of $10 \mathrm{Kg} / \mathrm{cm}^{2}$ for 5 hours. Composites thus prepared were subjected for the evaluation of different mechanical properties. The numbers of specimen used for the determination of mechanical properties were three and the tests were conducted at ambient laboratory conditions.

\section{Wear test}

Wear resistance of composites was carried-out as per ASTM D 3702 on DUCOM make machine. Wear resistance was conducted against hardened steel disc having hardness of 60 HRC and roughness Ra: $0.5 \mu \mathrm{m}$. Counter surface was polished using emery paper and cleaned with acetone before each sliding test. Samples $(3 \mathrm{~cm})$ for wear test were held against rotating counter surface at different speeds (100-600 RPM) and normal loads (1-4 Kg). Each test was conducted for 5 minutes of sliding. Loss of weight was used as a measure of wear.

\section{Modulus of rupture and modulus of elasticity}

MOR and MOE were determined according to ASTM D 790 in a universal testing machine and were calculated by using the following equations:

$$
\begin{aligned}
& \text { MOR }=\frac{3 \mathrm{PL}}{2 \mathrm{bd}^{2}} \mathrm{~N} / \mathrm{mm}^{2} \\
& \mathrm{MOE}=\frac{\mathrm{P}_{1} \mathrm{~L}^{3}}{4 \mathrm{bd}^{3} \mathrm{y}} \mathrm{N} / \mathrm{mm}^{2}
\end{aligned}
$$

Where $\mathrm{P}=$ peak load, $\mathrm{L}=$ length of sample, $\mathrm{b}=$ width of the sample, $\mathrm{d}=$ thickness of the sample, $\mathrm{P}_{1}=$ load at the limit of proportionality and $\mathrm{y}=$ rate of bending.

\section{Stress at the limit of proportionality}

Stress at the limit of proportionality was calculated by using the following equation:

$$
\mathrm{SP}=\frac{3 \mathrm{P}_{1} \mathrm{~L}}{2 \mathrm{bd}^{2}} \mathrm{~N} / \mathrm{mm}^{2}
$$

Where $\mathrm{P}_{1}=$ load at the limit of proportionality, $\mathrm{L}=$ length of sample, $\mathrm{b}=$ width of the sample and $d=$ thickness of the sample.

\section{Results and Discussion}

$\mathrm{C}_{2}, \mathrm{C}_{3}$ and $\mathrm{C}_{6}$ hydroxyls and the $\mathrm{C}-\mathrm{H}$ groups are the active cites for grafting in cellulosic fibers. The grafting onto flax fibers in presence of $\mathrm{FAS}-\mathrm{H}_{2} \mathrm{O}_{2}$ takes place as per the mechanism proposed by Misra et al ${ }^{16}$.

Optimum reaction conditions for getting maximum graft yield in case of graft copolymerization of MMA onto flax fiber in air (41.74\%) and under the influence of microwave radiations $(24.64 \%)$ were : $\mathrm{MMA}\left(\mathrm{mol} \mathrm{L}^{-1}\right)=1.96 \times 10^{-3}, \mathrm{FAS}-\mathrm{H}_{2} \mathrm{O}_{2}$ (molar ratio) $=1: 6$, temperature $\left({ }^{\circ} \mathrm{C}\right)=55$, time $($ minutes $)=120, \mathrm{pH}=7.0$ and MMA $\left(\mathrm{mol} \mathrm{L}^{-1}\right)=$ $1.96 \times 10^{-3}$, FAS : $\mathrm{H}_{2} \mathrm{O}_{2}$ (molar ratio) $=1: 6$, time (minutes) $=30, \mathrm{pH}=7.0$, respectively. 
In air graft co-polymerization of binary vinyl monomer mixtures such as MMA + EA, $\mathrm{MMA}+\mathrm{AN}, \mathrm{MMA}+\mathrm{AA}, \mathrm{MMA}+\mathrm{VA}, \mathrm{MMA}+\mathrm{AAm}$ and MMA + Sty onto flax fiber using MMA $\left(1.96 \times 10^{-3} \mathrm{~mol} \mathrm{~L}^{-1}\right)$ as the principal monomer showed $86.02 \%(\mathrm{EA}=$ $\left.1.84 \times 10^{-3} \mathrm{~mol} \mathrm{~L}^{-1}\right), 68.66 \%\left(\mathrm{AN}=3.79 \times 10^{-3} \mathrm{~mol} \mathrm{~L}^{-1}\right), 35.26 \%\left(\mathrm{AA}=3.64 \times 10^{-3} \mathrm{~mol} \mathrm{~L}^{-1}\right)$, $71.44 \%\left(\mathrm{VA}=2.70 \times 10^{-3} \mathrm{~mol} \mathrm{~L}^{-1}\right), 68.04 \%\left(\mathrm{AAm}=1.40 \times 10^{-3} \mathrm{~mol} \mathrm{~L}^{-1}\right)$ and $37.48 \%($ Sty $\left.=1.30 \times 10^{-3} \mathrm{~mol} \mathrm{~L}^{-1}\right)$ grafting, respectively. Whereas, grafting of binary vinyl monomer mixtures such as MMA + EA, MMA + AN, MMA + AA, MMA + VA, MMA + AAm and MMA + Sty onto flax fiber under the influence of micro-wave radiations using MMA $\left(1.96 \times 10^{-3} \mathrm{~mol} \mathrm{~L}^{-1}\right)$ as the principal monomer showed $51.20 \%\left(\mathrm{EA}=2.30 \times 10^{-3} \mathrm{~mol} \mathrm{~L}^{-1}\right)$, $17.80 \%\left(\mathrm{AN}=2.27 \times 10^{-3} \mathrm{~mol} \mathrm{~L}^{-1}\right), 12.08 \%\left(\mathrm{AA}=2.91 \times 10^{-3} \mathrm{~mol} \mathrm{~L}^{-1}\right), 48.84 \%(\mathrm{VA}=$ $\left.2.16 \times 10^{-3} \mathrm{~mol} \mathrm{~L}^{-1}\right), 27.7 \%\left(\mathrm{AAm}=1.05 \times 10^{-3} \mathrm{~mol} \mathrm{~L}^{-1}\right)$ and $24.04 \% \quad\left(\right.$ Sty $=1.30 \times 10^{-3}$ mol L ${ }^{-1}$ ) grafting, respectively (Table 1).

Table 1. Effect of concentrations of different binary monomer mixtures on percent grafting under different reaction conditions

\begin{tabular}{cclcc}
\hline S. No. & $\begin{array}{c}\text { Reaction } \\
\text { Condition }\end{array}$ & Binary Monomers & $\begin{array}{c}\text { Concentrations, } \\
10^{-3} \mathrm{molL}^{-1}\end{array}$ & $\mathrm{P}_{\mathrm{g}}$ \\
\hline & & MMA + EA & $1.96+1.84$ & 86.02 \\
& & $1.96+3.79$ & 68.66 \\
\multirow{4}{*}{ 1. } & In Air & MMA + AN & $1.96+3.64$ & 35.26 \\
& & MMA + VA & $1.96+2.70$ & 71.44 \\
& & MMA + AAm & $1.96+1.40$ & 68.04 \\
& MMA + Sty & $1.96+1.30$ & 37.48 \\
\hline \multirow{4}{*}{ 2. } & MMA + EA & $1.96+2.30$ & 51.20 \\
& Microwave & MMA + AN & $1.96+2.27$ & 17.80 \\
& Radiations & MMA + AA & $1.96+2.91$ & 12.08 \\
& & MMA + AAm & $1.96+2.16$ & 48.84 \\
& & MMA + Sty & $1.96+1.05$ & 27.70 \\
& & & $1.96+1.30$ & 24.04 \\
\hline
\end{tabular}

Mechanical properties of flax-g-copolymers reinforced phenol-formaldehyde composites

Wear Test

As is evident from Fig. 1 that phenol-formaldehyde matrix showed 18, 34, 56 and $77 \mathrm{gm} / \mathrm{m}$ x $10^{-4}$ wear rate and flax fiber reinforced PF composites showed 10, 14, 17 and $21 \mathrm{gm} / \mathrm{m}$ $\mathrm{x} 10^{-4}$ wear rate at $1,2,3$ and $4 \mathrm{Kg}$ loads, respectively. The reinforcement with graft copolymer prepared in air (IA) such as flax-g-poly(MMA); flax-g-poly(MMA/EA); flax-gpoly(MMA/AN); flax-g-poly(MMA/AA); flax-g-poly(MMA/VA); flax-g-poly(MMA/AAm)

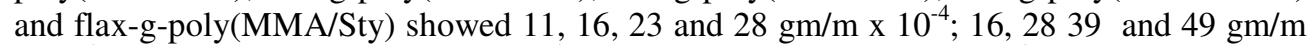
$\mathrm{x} 10^{-4} ; 14,25,36$ and $45 \mathrm{gm} / \mathrm{m} \mathrm{x} 10^{-4} ; 13,19,28$ and $34 \mathrm{gm} / \mathrm{m} \mathrm{x} 10^{-4} ; 23,35,47$ and 59 $\mathrm{gm} / \mathrm{m} \mathrm{x} 10^{-4} ; 19,32,45$ and $52 \mathrm{gm} / \mathrm{m} \mathrm{x} 10^{-4}$ and $13,18,27$ and $38 \mathrm{gm} / \mathrm{m} \mathrm{x} 10^{-4}$ wear rate at 1, 2, 3 and $4 \mathrm{Kg}$ loads, respectively.

In case of phenol-formaldehyde composite, weight loss takes place by the mechanism of abrasion and frictional heat generated due to sliding. However, reinforcement of the PF resin with flax fiber resulted in improved wear resistance. Moreover, reinforcement with graft copolymers could improve the wear resistance but wear rate keeps on increasing with 
increase in load from $1 \mathrm{Kg}$ to $4 \mathrm{Kg}$. Whereas, in case of reinforcement of the phenolformaldehyde matrix with flax fiber, increase in wear rate is minimum with increase in load. However, flax-g-poly(MMA) reinforcement showed better wear resistance and was almost nearer to that shown by flax fiber as reinforcing agent. Maximum weight loss has been found in case of phenol-formaldehyde matrix followed by reinforcement with flax-gpoly(MMA/VA), flax-g-poly(MMA/AAm), flax-g-poly(MMA/EA), flax-gpoly(MMA/AN), flax-g-poly(MMA/Sty) and flax-g-poly(MMA/AA). This could be due to weakening of the fiber strength during grafting. On grafting, the crystalline structure of the fiber gets disturbed and it becomes more amorphous, thereby, resulting in reduced wear resistance.

Reinforcement with graft copolymers prepared under the influence of micro-wave radiations (MWR) such as flax-g-poly(MMA), flax-g-poly(MMA/EA); flax-gpoly(MMA/AN); flax-g-poly(MMA/AA); flax-g-poly(MMA/VA); flax-g-poly(MMA/AAm)

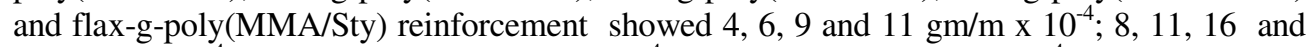

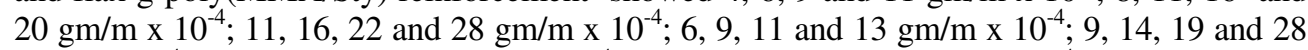
$\mathrm{gm} / \mathrm{m} \mathrm{x} 10^{-4} ; 12,17,21$ and $25 \mathrm{gm} / \mathrm{m} \mathrm{x} 10^{-4}$ and $6,11,14$ and $16 \mathrm{gm} / \mathrm{m} \mathrm{x} 10^{-4}$ wear rate at 1,2 , 3 and $4 \mathrm{Kg}$ loads, respectively.

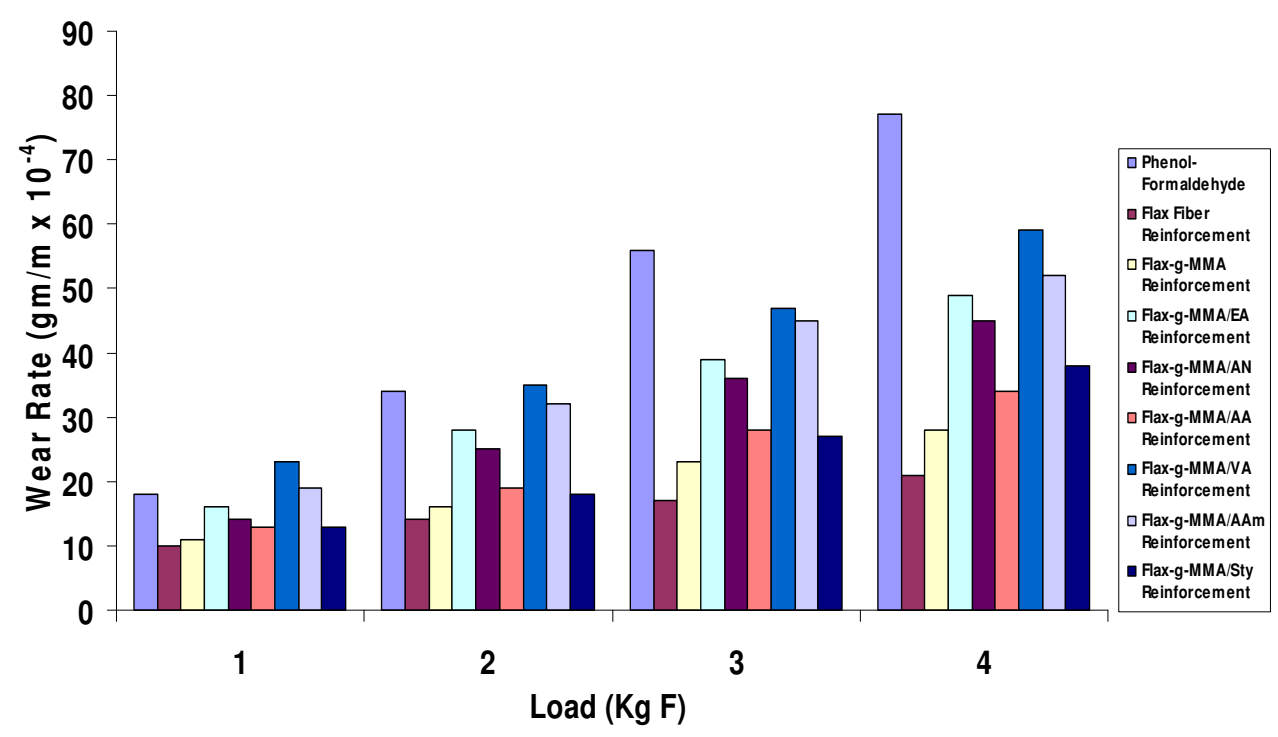

Fig. 1 Effect of Flax Fiber and Graft Co-polymers (IA) Reinforcement on Wear Rate of the Phenol-Formaldehyde Composites

Maximum wear resistance has been found in case of samples reinforced with graft copolymers prepared under the influence of micro-wave radiations (Fig. 2) in comparison to the samples reinforced with graft copolymers prepared in air as well as the flax fiber. Reinforcement of phenol-formaldehyde matrix with flax-g-poly(MMA) and flax-gpoly(MMA/AA) has been found to offer maximum wear resistance. flax-g-poly(MMA/Sty) and flax-g-poly(MMA/EA) reinforced samples also exhibited more wear resistance as compared to reinforcement with flax fiber. Whereas reinforcement of matrix with flax-gpoly(MMA/AAm), flax-g-poly(MMA/VA) and flax-g-poly(MMA/AN) had the wear rate nearer to that of reinforcement with flax fiber. 


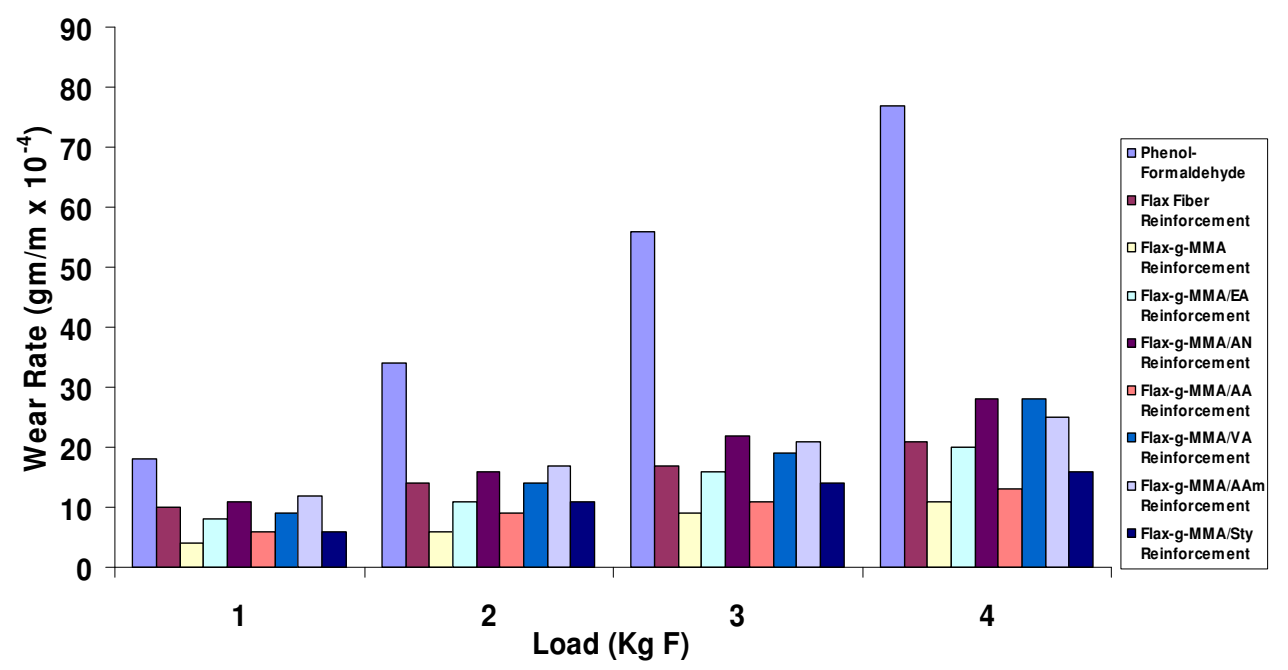

Fig. 2 Effect of Flax Fiber and Graft Co-polymers (MWR) Reinforcement on Wear Rate of the Phenol-Formaldehyde Composites

\section{Modulus of rupture}

MOR for phenol-formaldehyde and composites reinforced with flax fiber has been found to be 36 and $72 \mathrm{~N} / \mathrm{mm}^{2}$, respectively. On the other hand, in case of reinforcement with graft copolymers (IA): flax-g-poly(MMA), flax-g-poly(MMA/EA), flax-g-poly(MMA/AN), flaxg-poly(MMA/AA), flax-g-poly(MMA/VA), flax-g-poly(MMA/AAm) and flax-gpoly(MMA/Sty) MOR values were 84.0, 36.0, 48.0, 48.0, 16.8, 16.8 and $48.0 \mathrm{~N} / \mathrm{mm}^{2}$, respectively (Table 2). However, composites reinforced with graft copolymers (MWR): flax-g-poly(MMA), flax-g-poly(MMA/EA), flax-g-poly(MMA/AN), flax-gpoly(MMA/AA), flax-g-poly(MMA/VA), flax-g-poly(MMA/AAm) and flax-gpoly(MMA/Sty) showed 72.0, 72.0, 72.0, 108.0, 24.0, 16.8 and $72.0 \mathrm{~N} / \mathrm{mm}^{2}$ values for MOR, respectively (Table 3 ).

It is quite evident from above results that reinforcement of graft copolymers prepared under the influence of MWR resulted in higher MOR. Whereas, the reinforcement with graft copolymers prepared in air resulted in decreased MOR. Maximum values of MOR was found to be $108 \mathrm{~N} / \mathrm{mm}^{2}$ for PF composites reinforced with flax-g-poly(MMA/AA)-MWR.

\section{Modulus of elasticity}

The MOE of phenol-formaldehyde and flax fiber reinforced PF composites were found to be 1336.32 and $3280.64 \mathrm{~N} / \mathrm{mm}^{2}$, respectively. In case of reinforcement with graft copolymers (IA): flax-g-poly(MMA), flax-g-poly(MMA/EA), flax-g-poly(MMA/AN), flax-gpoly(MMA/AA), flax-g-poly(MMA/VA), flax-g-poly(MMA/AAm) and flax-gpoly(MMA/Sty), values of MOE were found to be 4166.14, 1391.62, 1900.80, 1828.35, 733.18, 684.80 and $2002.43 \mathrm{~N} / \mathrm{mm}^{2}$, respectively (Table 2). However, composites reinforced with graft copolymers (MWR): flax-g-poly(MMA), flax-g-poly(MMA/EA), flax-gpoly(MMA/AN), flax-g-poly(MMA/AA), flax-g-poly(MMA/VA), flax-g-poly(MMA/AAm) and flax-g-poly(MMA/Sty) showed 3490.56, 3395.58, 3440.13, 5295.62, 1011.71, 734.21 and $3485.44 \mathrm{~N} / \mathrm{mm}^{2}$ values for MOE, respectively (Table 3). 
PF Composites reinforced with graft copolymers prepared under the influence of microwave radiations showed the maximum values of MOE. Maximum value of MOE were found to be $5295.62 \mathrm{~N} / \mathrm{mm}^{2}$ for the composites reinforced with flax-g-poly(MMA/AA)MWR. Maximum MOE values were obtained with reinforcement of graft copolymers (MWR) followed with reinforcement of PF composites with graft copolymers (IA).

Table 2. MOR, MOE and SP values of PF and composites reinforced with graft copolymers prepared in air

\begin{tabular}{lccc}
\hline \multicolumn{1}{c}{ Sample } & $\begin{array}{c}\text { MOR } \\
\mathrm{N} / \mathrm{mm}^{2}\end{array}$ & $\begin{array}{c}\mathrm{MOE} \\
\mathrm{N} / \mathrm{mm}^{2}\end{array}$ & $\begin{array}{c}\mathrm{SP} \\
\mathrm{N} / \mathrm{mm}^{2}\end{array}$ \\
\hline Phenol-Formaldehyde & 36.0 & 1336.32 & 25.06 \\
Flax fiber Reinforcement & 72.0 & 3280.64 & 61.51 \\
Flax-g-poly(MMA) Reinforcement & 84.0 & 4166.14 & 78.12 \\
Flax-g-poly(MMA/EA) Reinforcement & 36.0 & 1391.62 & 26.09 \\
Flax-g-poly(MMA/AN) Reinforcement & 48.0 & 1900.80 & 35.64 \\
Flax-g-poly(MMA/AA) Reinforcement & 48.0 & 1828.35 & 34.28 \\
Flax-g-poly(MMA/VA) Reinforcement & 16.8 & 733.18 & 12.89 \\
Flax-g-poly(MMA/AAm) Reinforcement & 16.8 & 684.80 & 12.84 \\
Flax-g-poly(MMA/Sty) Reinforcement & 48.0 & 2002.43 & 37.55 \\
\hline
\end{tabular}

Stress at the limit of proportionality

Phenol-formaldehyde and flax fiber reinforced composites showed 25.06 and $61.51 \mathrm{~N} / \mathrm{mm}^{2}$ values for SP, respectively. The values of SP for composites reinforced with graft copolymers (IA): flax-g-poly(MMA), flax-g-poly(MMA/EA), flax-g-poly(MMA/AN), flax-gpoly(MMA/AA), flax-g-poly(MMA/VA), flax-g-poly(MMA/AAm) and flax-gpoly(MMA/Sty) were 78.12, 26.09, 35.64, 34.28, 12.89, 12.84 and $37.55 \mathrm{~N} / \mathrm{mm}^{2}$, respectively (Table 2). The values of SP for composites reinforced with graft copolymers (MWR): flax-gpoly(MMA), flax-g-poly(MMA/EA), flax-g-poly(MMA/AN), flax-g-poly(MMA/AA), flax-gpoly(MMA/VA), flax-g-poly(MMA/AAm) and flax-g-poly(MMA/Sty) were 65.45, 63.68, $64.50,99.29,18.97,13.77$ and $65.35 \mathrm{~N} / \mathrm{mm}^{2}$, respectively (Table 3).

It has been observed that PF composites reinforced with graft copolymers prepared under MWR showed maximum values for SP followed by reinforcement with graft copolymers prepared in air. Maximum and minimum values for SP were 99.29 and $11.70 \mathrm{~N} / \mathrm{mm}^{2}$.

Table 3. MOR, MOE and SP values of PF and composites reinforced with graft copolymers prepared under the influence of microwave radiations.

\begin{tabular}{lccc}
\hline \multicolumn{1}{c}{ Sample } & $\begin{array}{c}\text { MOR } \\
\text { N/mm }\end{array}$ & $\begin{array}{c}\text { MOE } \\
\text { N/mm }\end{array}$ & $\begin{array}{c}\text { SP } \\
\text { N/mm }\end{array}$ \\
\hline Phenol-Formaldehyde & 36.0 & 1336.32 & 25.06 \\
Flax fiber Reinforcement & 72.0 & 3280.64 & 61.51 \\
Flax-g-poly(MMA) Reinforcement & 72.0 & 3490.56 & 65.45 \\
Flax-g-poly(MMA/EA) Reinforcement & 72.0 & 3395.58 & 63.68 \\
Flax-g-poly(MMA/AN) Reinforcement & 72.0 & 3440.13 & 64.50 \\
Flax-g-poly(MMA/AA) Reinforcement & 108.0 & 5295.62 & 99.29 \\
Flax-g-poly(MMA/VA) Reinforcement & 24.0 & 1011.71 & 18.97 \\
Flax-g-poly(MMA/AAm) Reinforcement & 16.8 & 734.21 & 13.77 \\
Flax-g-poly(MMA/Sty) Reinforcement & 72.0 & 3485.44 & 65.35 \\
\hline
\end{tabular}


Phenolic composites reinforced with graft copolymers prepared under the influence of micro-wave radiations showed better mechanical properties due to the reason that optimum reaction time for grafting was very low and thus the fiber underwent a fewer disturbances in its crystal structure. Moreover, fiber faces less surface deformations during grafting process under the influence of microwaves as compared to grafting in air, thereby retaining better mechanical properties with better fiber-matrix interaction.

\section{Conclusion}

Microwave enhanced Graft copolymerization is an effective method for modifying the properties of natural fibers in terms of time consumption and cost effectiveness. Flax-gcopolymers-MWR showed better mechanical properties in comparison to flax-gcopolymers-IA and flax fibers reinforcement.

\section{References}

1. Mestdagh M and Demeulemeester M, Holz als Roh- und Werkstoff, 1970, 28, 209.

2. Bentsianova I Y, Veksler G M, Markov L R, Melamed S N and Petrienko P M, Derevoobrabatyrayushchaya Promyshlennost, 11, 9 (1962).

3. Kolosvary G, Faipar, 1965, 15, 46.

4. Klingel W, "Weatherproof building material from vermiculite and wastes", Assignee: Klingel, Hans. Patent, P. N.: DE 2125453, I. D.: 721221, 1972.

5. Bouhicha M, Aouissi F and Kenai S, Cement and Concrete Composites, 2005, 27, 617.

6. Paramasivam T and Abdul Kalam A P J., Fiber Science and Technology, 1974,7, 85.

7. Lee S M, Cho D, Park W H, Lee S G, Han S O K and Drzal L T, Compos. Sci. Technol., 2005, 65, 647.

8. Joseph S, Sreekala M S, Oommen Z, Koshy P and Thomas S, Compos. Sci. Technol., 2002, 62, 1857.

9. Aranberri-Askargorta I, Lampke T and Bismarck A, Journal of Colloid and Interface Science, 2003, 263, 580.

10. Canche-Escamilla G, Cauich-Cupul J I, Mendizabal E, Puig J E, Vazquez-Torres H and Herrera-Franco P J, Composites Part A: Applied Science and Manufacturing, 1999, 30, 349.

11. Singha A S, Kumar S and Kaith B S, Int. J. Plast. Tech., 2005, 9, 427.

12. Kaith B S, Singha A S, Dwivedi D K, Kumar S, Kumar D and Dhemeniya A, Int. J. Plast. Tech., 2003, 7, 119.

13. Dwivedi D K, Singha A S, Kumar S and Kaith B S, Int. J. Plast. Tech., 2004, 8, 299.

14. Kaith B S, Singha A S and Susheel Kalia, Int. J. Plast. Tech., 2006, 10, 572.

15. Kaith B S, Singha A S and Susheel Kalia, Autex Res. J., 2007, 7, $119 .$.

16. Misra B N., Chandel P S and Dogra R, J Polymer Science, Polymer Chemistry Ed., 1978, 16, 1801. 


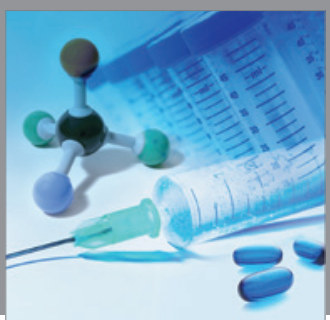

International Journal of

Medicinal Chemistry

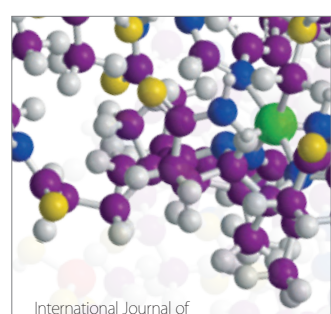

Carbohydrate Chemistry

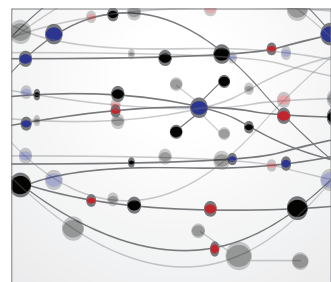

The Scientific World Journal
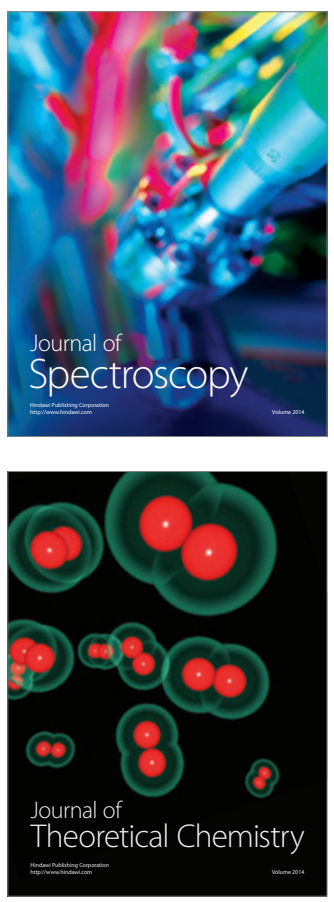
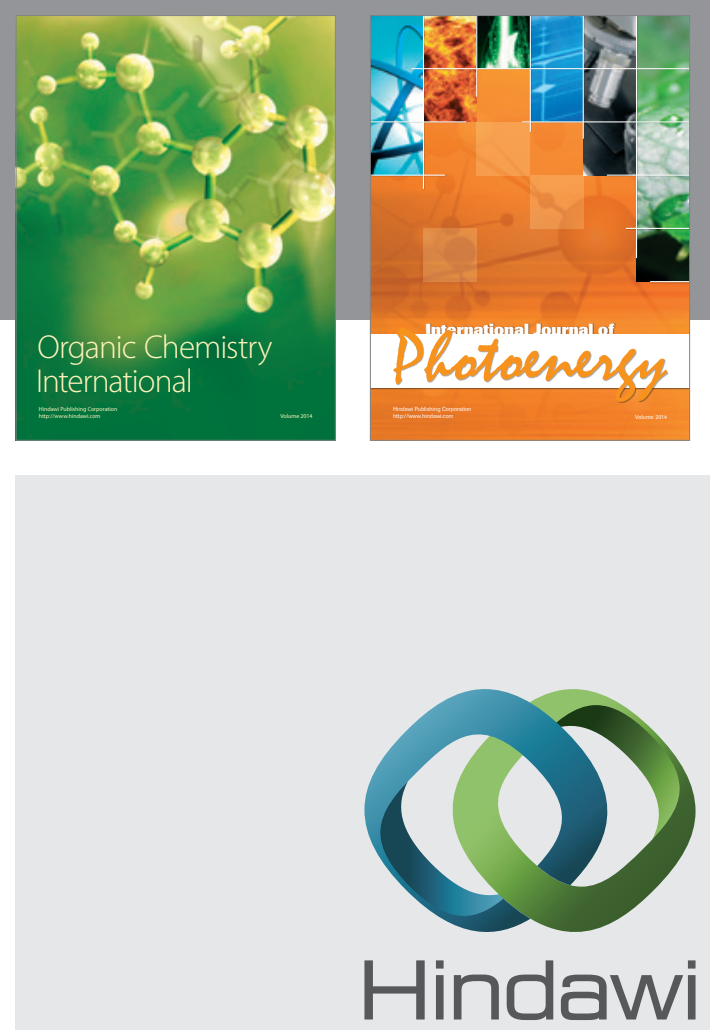

Submit your manuscripts at

http://www.hindawi.com
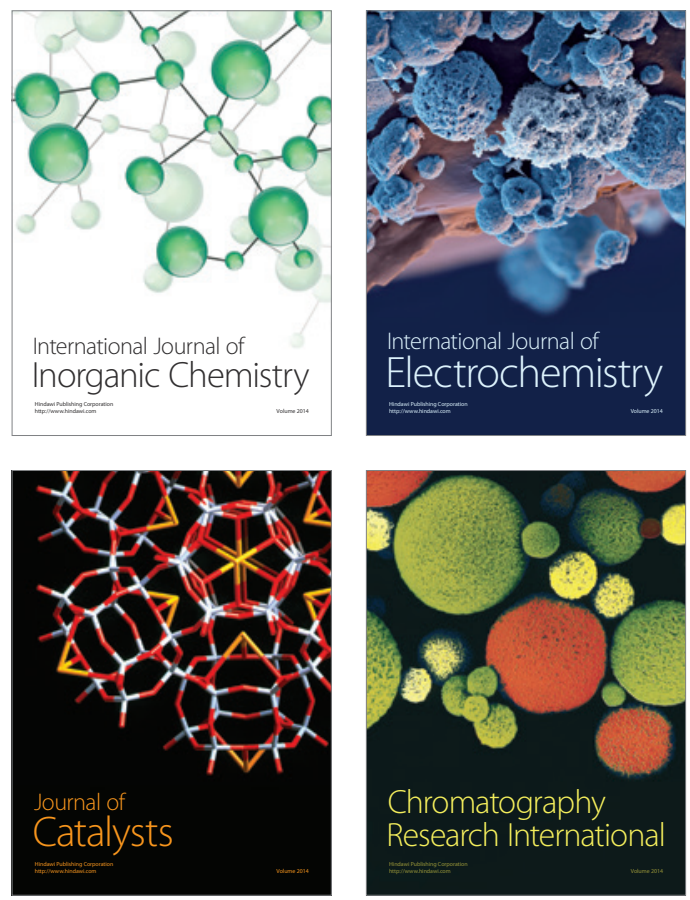
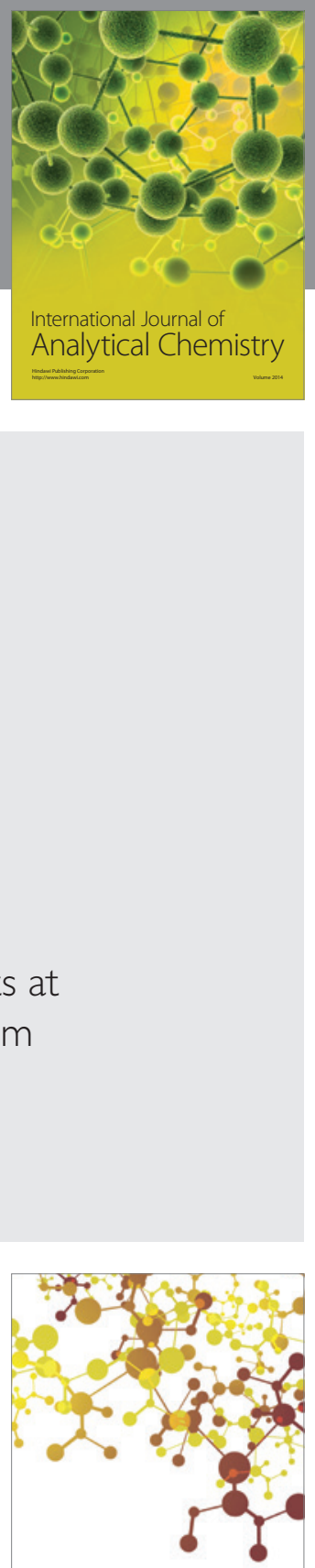

Journal of

Applied Chemistry
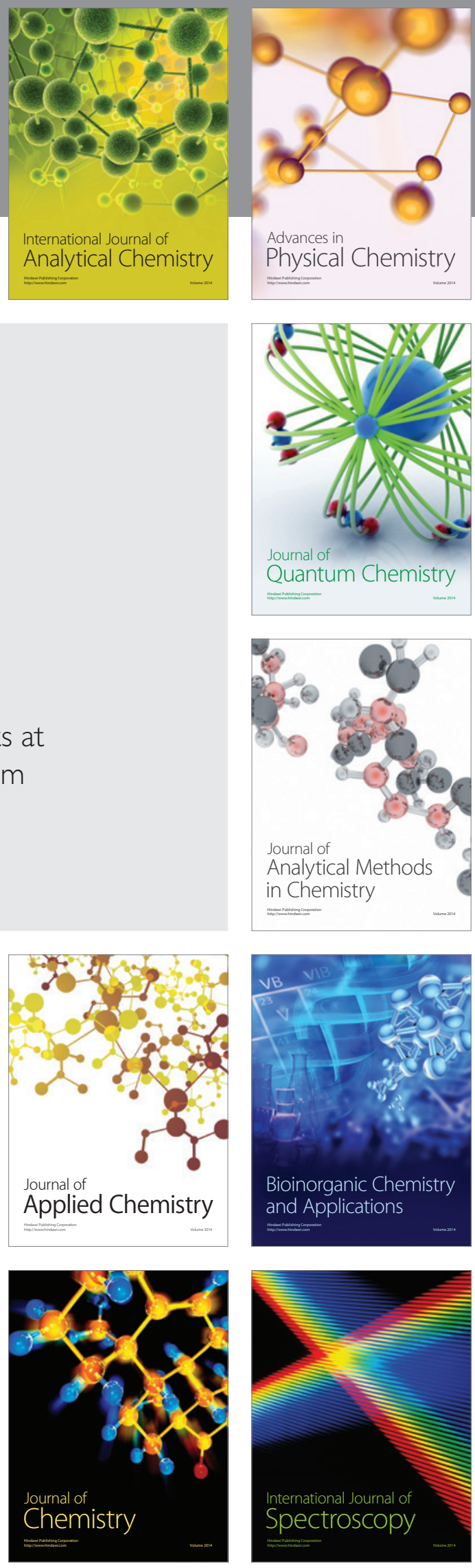